\title{
Mechanical properties and strain hardening behavior of phase reversion-induced nano/ultrafine Fe-17Cr-6Ni austenitic structure steel
}

\author{
Chengshuai Lei ${ }^{\text {a }}$, Xiangtao Deng ${ }^{\text {a, }}$, Xiaolin Li $^{\text {a }}$, Zhaodong Wang ${ }^{\text {a, }}$, Guodong Wang ${ }^{\text {a }}$, R.D.K. \\ Misra $^{b}$ \\ ${ }^{a}$ State Key Laboratory of Rolling and Automation, \\ Northeastern University, Shenyang 110004, PR China \\ ${ }^{\mathrm{b}}$ Laboratory for Excellence in Advanced Steel Research, \\ Department of Metallurgical, Materials and Biomedical Engineering, \\ University of Texas at El Paso, El Paso, TX 79968-0521, USA
}

\begin{abstract}
Nano/ultrafine-grained (Nano/UFG) structure was obtained in $\mathrm{Fe}-17 \mathrm{Cr}-6 \mathrm{Ni}$ austenitic steel using a combination of severe cold deformation and reverse-transformation annealing. The microstructural evolution during severe cold reduction and annealing was studied to elucidate the effect of grain size on mechanical properties and strain hardening behavior. Austenitic steel with the smallest average grain size of $\sim 220 \mathrm{~nm}$ was obtained and exhibited a good combination of high strength and high ductility when the cold reduction was $\sim 75 \%$ and annealing was carried out at $700{ }^{\circ} \mathrm{C}$ for $20 \mathrm{~s}$. The relationship between grain size and yield strength was in good agreement with Hall-Petch relationship until 200 nm grain size. For coarse-grained steel, the strain hardening rate (SHR) plots comprised of 4 stages and the increase of SHR was attributed to deformation-induced martensite transformation (DIMT). While for Nano/UFG ASS, the SHR plots contained only 3 stages and the increase of SHR was attributed to the comprehensive effect of DIMT and twining.
\end{abstract}

Key words: high strength; high ductility; strain hardening; nano/ultrafine grained structure

\footnotetext{
* Corresponding author. Tel.:+86 24 83686426; fax: +86 2423906472

E-mail address: dengxiangtao123@163.com (X.T. Deng), zhdwang@ mail.neu.edu.cn (Z.D. Wang).
} 


\section{Introduction}

There is continued and significant interest in recent years to develop new generation of advanced steels with high strength and high ductility combination for light-weight applications, including austenitic stainless steels (ASSs) [1, 2]. ASSs have good corrosion resistance and good formability but extremely low yield strength which limits their application in engineering. In this context, grain refinement can improve the strength and toughness simultaneously and is a viable approach to enhance the mechanical properties of ASSs $[3,4]$. Severe plastic deformation (SPD) techniques are considered to be the effective methods for grain refinement, which can produce ultrafine grained (UFG) materials $(\mathrm{d}=100-500 \mathrm{~nm})$ and even nanocrystalline materials $(\mathrm{d}<100 \mathrm{~nm})$ [5]. Even though ultrahigh strength has been realized in Nano/UFG materials fabricated by SPD techniques, the problem is that the ductility of the material is extremely low. Furthermore, the limit of shape and size of the material and demand for forming equipment also limits the application of SPD techniques.

The reversion of deformation-induced martensite (DIM) to austenite in metastable ASSs enables grain refinement at bulk scale [6]. This process consisted of severe cold reduction (over $70 \%$ reduction in thickness) to induce transformation of austenite to martensite followed by annealing when martensite reverts to Nano/UFG austenitic structure [6-11]. Given that the process contains only conventional cold rolling and annealing, it is more appropriate for large-size sheets, and has potential for actual applications, compared to SPD techniques [12].

Based on previous studies [10, 13], Nano/UFG ASSs obtained by phase reversion process exhibited ultrahigh strength without sacrificing much ductility. The high ductility was attributed to enhanced strain hardening ability. It is known that $[14,15]$ in nano/ultrafine structure obtained by 
SPD techniques, grain boundary shear plays a major role during deformation. Shear deformation encourages shear bands or localized deformation and this decreases strain hardening ability and promotes the onset of necking. However in the case of nano/ultrafine structure obtained by phase reversion process, the equiaxed and defect-free grains can increase the ability to accommodate dislocations and correspondingly increase the strain hardening ability. The deformation-induced martensite transformation (DIMT) or twining during deformation of metastable austenite is expected to increase the ductility $[10,16]$. The DIMT or twining during deformation can release the localized stress, restrict localized deformation and delay the onset of necking. On the other hand the DIM or twins can act as obstacles for dislocation motion and transfer of strain to the matrix, and finally harden the entire material.

Thus, to obtain the excellent ductility during deformation for Nano/UFG ASS, the strain hardening ability is required as a stabilizing effect to control the instability and delay necking [10]. In this context, Nano/UFG ( 220nm) ASS with ultrahigh strength and good ductility was obtained using the procedure described earlier $[1,10,12,14]$. The objective of this study is to study the effect of grain size on tensile properties and strain hardening behavior.

\section{Materials and Experimental Procedures}

The experimental material used in this study was Fe-17Cr-6Ni austenitic stainless steel, and the chemical composition (in weight percent) is presented in Table 1 . The $\mathrm{M}_{\mathrm{d} 30}$ temperature and $\mathrm{M}_{\mathrm{s}}$ was $38.7{ }^{\circ} \mathrm{C}$ and $-90.4{ }^{\circ} \mathrm{C}$ respectively, and are indicative of stability of austenite. The optical micrograph illustrating the microstructure of the as-received steel is presented in Fig. 1.The austenite had an average grain size of $25.3 \mu \mathrm{m}$ and many annealing twins could be observed. The thickness of 
the initial steel strip was $1.5 \mathrm{~mm}$ and was cold rolled to $\sim 0.35 \mathrm{~mm}$ at room temperature with a reduction of $\sim 75 \%$ in thickness. Following cold rolling, annealing was carried out in a continuous annealing furnace with annealing temperature in the range of $700-900{ }^{\circ} \mathrm{C}$ for different times. Heating rate and cooling rate were both $40^{\circ} \mathrm{C} \mathrm{s}^{-1}$.

Tensile specimens of dimensions $6.25 \mathrm{~mm}$ width and $25 \mathrm{~mm}$ gage length were cut from the cold rolled and annealed samples. Prior to the tensile tests, the samples were mechanically-polished to remove the uneven surface. Uniaxial tensile tests were carried out at room temperature at a cross-head speed of $3 \mathrm{~mm} \mathrm{~min}^{-1}$.

The samples for optical and SEM studies were mechanically polished and then electrochemically etched with $60 \%$ nitric acid solution. Thin foils of $3 \mathrm{~mm}$ diameter for TEM observations were cut from the cold rolled and annealed samples. The thin foils were firstly mechanically polished to a thickness of $50 \mu \mathrm{m}$ and then twin-jet electro-polished in a solution containing 9 vol. \% perchloric acid in ethanol at $243 \mathrm{~K}$. TEM observations were performed in a FEI Tecnai $\mathrm{G}^{2}$ F20 TEM microscope, operating at an accelerated voltage of $200 \mathrm{kV}$.

The average grain size was calculated from the TEM micrographs by linear intercept method and EBSD data using more than 300 grains. Image-Pro Plus software was used for calculation.

The phase composition and the amount of strain-induced martensite was studied by X-ray diffraction experiments using $\mathrm{Cu} \mathrm{K} \alpha$ radiation. The peaks and the peak intensities were indexed and calculated by MDI Jade 6.0 software. Peaks of (110) $\alpha,(200) \alpha,(211) \alpha,(111) \gamma,(200) \gamma$ and (220) $\gamma$ were used for calculating martensite fraction based on the method firstly published by Dickson using Eq. (1) [17]. 


$$
\frac{\mathrm{C}_{\gamma}}{\mathrm{C}_{\alpha}}=\frac{\frac{1}{\mathrm{n}_{\gamma}} \sum_{0}^{\mathrm{n}_{\gamma}}\left(\frac{\mathrm{I}_{\gamma}}{\mathrm{R}_{\gamma}}\right)}{\frac{1}{\mathrm{n}_{\alpha}} \sum_{0}^{\mathrm{n}_{\alpha}}\left(\frac{\mathrm{I}_{\alpha}}{\mathrm{R}_{\alpha}}\right)}
$$

where $\mathrm{C}_{\alpha}=1 /\left[1+\left(\mathrm{C}_{\gamma} / \mathrm{C}_{\alpha}\right)\right], \mathrm{C}_{\gamma}=\left(\mathrm{C}_{\gamma} / \mathrm{C}_{\alpha}\right) /\left[1+\left(\mathrm{C}_{\gamma} / \mathrm{C}_{\alpha}\right)\right], \mathrm{n}_{\alpha}$ and $\mathrm{n}_{\gamma}$ are the number of martensite and austenite reflections, $I_{\alpha}$ and $I_{\gamma}$ are the integrated intensities of martensite and austenite for the reflections, and $\mathrm{R}_{\alpha}$ and $\mathrm{R}_{\gamma}$ are the relative intensities of martensite and austenite which are listed in Table 2 for the reflexions [18].

\section{Results and discussion}

\subsection{XRD Analysis}

Fig. 2 shows X-ray diffraction patterns for annealed samples along with the cold-rolled (CR) sample. It can be seen in Fig. 2 that the CR sample exhibited primarily martensite peaks with a small $\{220\}$ austenite peak, implying high martensite volume fraction in the cold rolled sample. Using the peak intensities obtained from X-ray diffraction and employing the procedure described in Section 2, the volume fraction of martensite in the CR sample was $\sim 95 \%$. On annealing at $700{ }^{\circ} \mathrm{C}$ for $20 \mathrm{~s}$, the austenite peaks $\{111\} \gamma$ and $\{311\} \gamma$ appeared, and intensity of $\{220\} \gamma$ peak was also increased, indicating reversion of cold deformation-induced martesite (DIM) to austenite. The volume fraction of DIM annealed at $700{ }^{\circ} \mathrm{C}$ for $20 \mathrm{~s}$ was decreased to $\sim 14 \%$. On annealing at higher temperatures, the martensite peaks were nearly absent and the volume fraction of DIM was only $\sim 2 \%$ on annealing at $750{ }^{\circ} \mathrm{C}$ for $5 \mathrm{~s}$.

\subsection{Microstructure of cold rolled samples}

Representative TEM micrographs illustrating the microstructural characteristics of cold rolled sample with $\sim 75 \%$ cold reduction (CR) are presented in Fig. 3 . The cold rolled sample showed a microstructure composed of two types of martensite: lath-type martensite outlined with red square, 
and dislocation cell-type martensite outlined with green square in Fig. 3(a). Fig. 3 (b), (c) are magnified micrographs of lath structure and dislocation cell structure, respectively. According to earlier studies $[10,13]$ dislocation cell-type martensite is preferred to obtain Nano/UFG structure because it contains higher dislocation density than the lath-type martensite, which provides nucleation site for the austenite during annealing [19-21].

\subsection{Microstructure and grain size of annealed samples}

The SEM and TEM micrographs of specimens with different grain sizes are presented in Fig. 4-5, respectively. The histograms in Fig. 5 provide grain size distribution of different specimens. nano/ultrafine structure with average grain size of $\sim 220 \mathrm{~nm}$ and distinct grain boundaries were obtained on annealing at $700{ }^{\circ} \mathrm{C}$ for $20 \mathrm{~s}$, as illustrated in Fig. 4(a) and Fig. 5(a). However, this microstructure was not completely austenitic and consisted of small amount of martensite, which was confirmed by XRD data in Fig. 2. Majority of the austenite grains including equiaxed and elongated ones were in the nano $(<100 \mathrm{~nm})$ or ultrafine $(100-500 \mathrm{~nm})$ regime. It was obvious that some austenite grains were still in the initial phase of reversion, which was confirmed by the presence of martensite and small grain size [22]. This microstructure is clearly different from that obtained by severe plastic deformation (SPD). The grain boundaries obtained by SPD techniques are generally curved or wavy, and not well defined [23]. However in our case, the boundaries were defined and residual internal stress in the annealed austenite was believed to be nearly absent [24].

The microstructure of the specimen annealed at $750{ }^{\circ} \mathrm{C}$ for $5 \mathrm{~s}$ is presented in Fig. 4(b) and Fig. 5(b), indicating mixed microstructure consisted of nano/ultrafine grains and micron grains. The austenite grains experienced significant grain growth and the average grain size for this specimen has 
increased to $\sim 400 \mathrm{~nm}$. One possible reason for the mixed structure can may be related to two reversion mechanisms (diffusional or shear type) operating during the annealing process [22, 25]. The first is expected to produce nano/ultrafine grains, while the second (usually complete within a short time) is expected to produce submicron or fine grains.

The microstructure of specimens annealed at $800{ }^{\circ} \mathrm{C}$ and higher temperatures are shown in Fig. 4 (c), (d) and Fig. 5(c), (d). A close examination of the microstructure of these specimens suggest the formation of large equiaxed defect-free austenite grains and there is an increase in the average grain size compared to the specimens annealed at lower temperatures. The large grain size is related to the grain growth at higher temperatures.

\subsection{The influence of grain size on mechanical properties}

The mechanical properties along with the microstructural features of the specimens are presented in Table 3. As depicted in Table 3, the cold rolled (CR) specimen exhibited very high tensile strength, approaching $\sim 1680 \mathrm{MPa}$, but extremely low elongation of $<5 \%$. This is because of the high volume fraction of martensite and high density of dislocations in the cold rolled steel. Depending on the annealing temperature $\left(700-900{ }^{\circ} \mathrm{C}\right)$, the yield strength was decreased and varied from $\sim 973 \mathrm{MPa}$ to $\sim 350 \mathrm{MPa}$, while the elongation was increased and varied from $\sim 31.5 \%$ to $\sim 55.5 \%$.

The specimen with an average grain size of $220 \mathrm{~nm}$ exhibited high yield strength of $\sim 973 \mathrm{MPa}$, and was $3-4$ times of the as-received steel. The high strength of Nano/UFG steel is mainly attributed to small austenite grain size. The total elongation was also high at $\sim 31.5 \%$, which is in contrast to the materials fabricated by SPD methods that are generally characterized by elongation of less than $10 \%$ [23]. It can be seen from the true stress-strain curve in Fig. 7 that, the specimen 
experienced significant strain hardening after the yield point and is discussed in the next section.

The specimen annealed with average grain size of $400 \mathrm{~nm}$ exhibited a combination of high yield strength ( 790 MPa) and high ductility ( 40.5\%) comparable with other specimens. It can be seen that the specimen with average grain size of $660 \mathrm{~nm}$ exhibited similar strength ( $762 \mathrm{MPa})$ but low ductility $(\sim 35.6 \%)$ and the specimen with average grain size of $1.23 \mu \mathrm{m}$ exhibited similar ductility $(\sim 42 \%)$ but low yield strength $(\sim 480 \mathrm{MPa})$. This behavior is attributed to the mixed microstructure consisting of nano/ultrafine grains and micron grains as illustrated in Fig. 4(b) and Fig. 5(b). The small grains provide high strength according to Hall-Petch relationship, and the relatively coarse grains provide ductility [26].

In order to further understand the variation in yield strength and ductility of all annealed samples, yield strength was plotted as a function of grain size. The behavior followed Hall-Petch relationship, given by:

$$
\sigma_{s}=\sigma_{0}+k d^{-0.5}
$$

where $\sigma_{\mathrm{s}}$ is the yield strength, $\sigma_{0}$ is the lattice friction stress, $\mathrm{k}$ is a constant, and $\mathrm{d}$ is the average grain size. Figure 6 shows liner dependence of yield strength with square-root of grain size. The grain size in Figure 6 covers a wide range, from nanoscale regime to micrometer scale. The data followed Hall-Petch relationship where $\sigma_{0}=207 \mathrm{MPa}$ and $\mathrm{k}=363 \mathrm{MPa} \mu \mathrm{m}^{0.5}$. The results are in agreement with previous studies [27, 28].

3.5. The influence of grain size on strain hardening behavior

ASSs with four different grain size $(220 \mathrm{~nm}, 400 \mathrm{~nm}, 1.23 \mu \mathrm{m}, 3.23 \mu \mathrm{m})$ were selected to study the strain hardening behavior. The true stress-strain $(\sigma-\varepsilon)$ curves of specimens with different grain 
sizes are presented in Fig. 7(a), which are all characterized by a transition point because of the microstructural evolution during plastic deformation [29]. However the transition point exists at different places with variation in grain size. It can be seen from Fig. 7(a) that, the transition point appeared immediately after the elastic deformation for specimens with $220 \mathrm{~nm}$ and $400 \mathrm{~nm}$ grain size, while for the specimens with larger grain size the transition point appeared at larger strains. Moreover, for the specimens with average grain size of $3.23 \mu \mathrm{m}$ referred as coarse grains, the strain hardening behavior showed a continuous increase in true stress with increase in true strain, while for the specimen with average grain size of $220 \mathrm{~nm}$ referred as nano/ultrafine grains, there was a small plateau before the continuous increase. To examine the characteristics of hardening in more detail, the strain hardening behavior was further analyzed.

The strain hardening rates (SHR; $d \sigma / d \varepsilon$ ) computed from the true stress-strain curves in Fig. 7(a) are plotted as a function of true strain in Fig. 7(b) for specimens with different grain sizes. In the case of specimen with coarse grains $(3.23 \mu \mathrm{m})$, four different deformation stages could be clearly distinguished in the evolution of SHR. In the first stage, referred as stage A, the SHR decreases dramatically at relatively low strains $(<0.03)$, indicating the onset of yielding. A marked discontinuity of SHR is obvious at this stage. In stage B, the decrease of SHR slowed down and finally reached a minimum at true strain of 0.2 . In stage $\mathrm{C}$, the SHR increased gradually with increasing strain and reached a maximum at true strain of $\sim 0.33$. In the last stage, referred as stage $\mathrm{D}$, the SHR decreased until the onset of necking. The representative micrographs illustrating the deformation microstructure along with the XRD spectra for this specimen at different stages are presented in Fig. 8. A large number of dislocations were observed at true strain of 0.1 (stage B), 
indicating that the mobility and rearrangement of dislocations is the dominant deformation mechanism in this stage. XRD analysis indicate that the volume fraction of martensite is only $\sim 2 \%$. So it can be concluded that the interactions of dislocations with grain boundaries is responsible for the slowing down of SHR and increase in ductility in stage B $[29,30]$. The lath martensite structure in the vicinity of the fracture region (stage D) is illustrated in Fig. 8 (b) along with the selected area electron diffraction pattern of the martensite. XRD analysis indicates a high volume fraction of martensite, reaching $\sim 76 \%$. The occurrence of lath martensite confirmed the strain-induced matensite transformation during stage $\mathrm{C}$ and stage $\mathrm{D}$. These results are consistent with the literature [29]: Misra et al. demonstrated in their research that the increase of SHR is due to the formation strain induced martensite.

However, for specimens with nano/ultrafine grains $(220 \mathrm{~nm})$, the plot had only 3 stages marked as A, C and D respectively. Stage B was absent in this case, which can be attributed to the large fraction of grain boundaries, which effectively promoted the nucleation of DIM and twins [29]. Fig. 9 shows the deformation structure (a), (b) at 0.1 true strain and (c), (d) after fracture. Fig. 9(a) shows the formation of deformation-induced martensite as well as deformed austenite at true strain of 0.1 (Stage C). It is difficult to distinguish the DIM and deformed austenite by visual because they both have high density of dislocations. The selected area electro diffraction pattern as illustrated in the internal illustration in Fig. 9(a) confirmed the formation of DIM. XRD analysis indicated that the volume fraction of martensite has reached $\sim 50 \%$. Deformation twins could also be observed in some nano/ultrafine grains at true strain of 0.1 (stage C) as shown in Fig. 9(b) and also after fracture (stage D) as shown in Fig. 9(c). XRD detection of the fracture region indicated the volume fraction of 
martensite has reached $\sim 92 \%$ after fracture. Thus, for specimens with nano/ultrafine grains, deformation-induced martensite transformation and deformation twining both contributed to the increase in SHR in stage C.

Deformation twins in Nano/UFG materials has been observed in many publications. Misra [31] et al found that there was a change in deformation mechanism from strain-induced martensite in the CG structure to twinning in the nano/ultrafine structure in ASS and they attributed twining in nano/ultrafine grians to the high stability of austenite compared to their coarse-grained counterparts. Deformation twins created by emitting Shockley partial dislocations from grain boundaries (GBs) in Nano/UFG material has been confirmed by molecular-dynamics simulation [32] and high resolution TEM analysis $[33,34]$. With decreasing grain size, the dislocation nucleation at GBs transforms from full dislocation emission to partial dislocation emission [35]. Huang [34] et al further investigated the shear stresses for full dislocations $\left(\tau_{\mathrm{S}}\right)$ and partial dislocations $\left(\tau_{\mathrm{P}}\right)$ in nanocrystalline $\mathrm{Cu}$ and they found that with grain size decreasing to a critical grain size $d_{c}, \tau_{P}$ would become greater than $\tau_{S}$ and twining would take place. $d_{c}$ was estimated to be several hundred nanometers in nanocrystalline $\mathrm{Cu}$.

In summary, both Nano/UFG and coarse-grained material exhibited good ductility because of the good strain hardening ability. However there was subtle difference in the strain hardening behavior. For nano/ultrafine grained material, deformation-induced martensite transformation and deformation twining both contributed to strain hardening ability and superior ductility, while for coarse grained material, ductility was also good but because of deformation-induced martensite transformation.

\section{Conclusions}

The mechanical properties and strain hardening behavior of $17 \mathrm{Cr}-6 \mathrm{Ni}$ austenitic nano/ultrafine 
structure steel obtained by combination of severe cold deformation and annealing were studied. The conclusions are:

(1) Severe cold deformation ( $75 \%$ reduction) followed by annealing effectively refined the austenite grain size. Smallest average grain size of $220 \mathrm{~nm}$ was obtained after $\sim 75 \%$ cold deformation and annealing at $700^{\circ} \mathrm{C}$ for $20 \mathrm{~s}$.

(2) Steel with nano/ultrafine structure exhibited a good combination of high strength and ductility. The highest yield strength, tensile strength and total elongation were $973 \mathrm{MPa}, 1073 \mathrm{MPa}$ and $31.5 \%$, respectively.

(3) The relationship between grain size and yield strength followed Hall-Petch relationship until $\sim 200 \mathrm{~nm}$.

(4) The strain hardening rate curve of coarse-grained ASS contained 4 stages, but the nano/ultrafine grained only contained 3 stages. The increase of strain hardening rate was attributed to deformation-induced martensite transformation in coarse-grained ASS, while in nano/ultrafine grained ASS deformation-induced martensite and deformation twining both take effect.

\section{Acknowledgments}

The authors gratefully acknowledge support from National Science Foundation of China (Grant No. $51474064,51234002,51504064)$. RDKM also gratefully acknowledges support from University of Texas at El Paso, USA. 


\section{References}

[1] C. Koch, Optimization of strength and ductility in nanocrystalline and ultrafine grained metals, Scripta Materialia, 49 (2003) 657-662.

[2] E. Ma, Instabilities and ductility of nanocrystalline and ultrafine-grained metals, Scripta Materialia, 49 (2003) 663-668.

[3] R. Song, D. Ponge, D. Raabe, J.G. Speer, D.K. Matlock, Overview of processing, microstructure and mechanical properties of ultrafine grained bcc steels, Materials Science and Engineering: A, 441 (2006) 1-17.

[4] R. Song, D. Ponge, D. Raabe, R. Kaspar, Microstructure and crystallographic texture of an ultrafine grained C - Mn steel and their evolution during warm deformation and annealing, Acta Materialia, 53 (2005) 845-858.

[5] Y.M. Wang, E. Ma, Three strategies to achieve uniform tensile deformation in a nanostructured metal, Acta Materialia, 52 (2004) 1699-1709.

[6] S. Takaki, K. Tomimura, S. Ueda, Effect of Pre-cold-working on Diffusional Reversion of Deformation Induced Martensite in Metastable Austenitic Stainless Steel, ISIJ International, 34 (1994) 522-527.

[7] K. Tomimura, S. Takaki, Y. Tokunaga, Reversion Mechanism from Deformation Induced Martensite to Austenite in Metastable Austenitic Stainless Steels, ISIJ International, 31 (1991) 1431-1437.

[8] K. Tomimura, S. Takaki, S. Tanimoto, Y. Tokunaga, Optimal Chemical Composition in Fe-Cr-Ni Alloys for Ultra Grain Refining by Reversion from Deformation Induced Martensite, ISIJ International, 31 (1991) 721-727.

[9] R.D.K. Misra, B.R. Kumar, M. Somani, P. Karjalainen, Deformation processes during tensile straining of ultrafine/nanograined structures formed by reversion in metastable austenitic steels, Scripta Materialia, 59 (2008) 79-82.

[10] R.D.K. Misra, S. Nayak, S.A. Mali, J.S. Shah, M.C. Somani, L.P. Karjalainen, Microstructure and Deformation Behavior of Phase-Reversion-Induced Nanograined/Ultrafine-Grained Austenitic Stainless Steel, Metallurgical and Materials Transactions A, 40 (2009) 2498 - 2509.

[11] M.C. Somani, P. Juntunen, L.P. Karjalainen, R.D.K. Misra, A.K.L. Inen, Enhanced Mechanical Properties through Reversion in Metastable Austenitic Stainless Steels, Metallurgical and Materials Transactions A, 40 (2009) 729-744.

[12] Y. MA, J. JIN, Y. LEE, A repetitive thermomechanical process to produce nano-crystalline in a metastable austenitic steel, Scripta Materialia, 52 (2005) 1311-1315.

[13] R.D.K. Misra, S. Nayak, P.K.C. Venkatasurya, V. Ramuni, M.C. Somani, L.P. Karjalainen, Nanograined/Ultrafine-Grained Structure and Tensile Deformation Behavior of Shear Phase Reversion-Induced 301 Austenitic Stainless Steel, Metallurgical and Materials Transactions A, 41 (2010) 2162 - 2174.

[14] E. Ma, Instabilities and ductility of nanocrystalline and ultrafine-grained metals, Scripta Materialia, 49 (2003) 663-668.

[15] Q. Wei, S. Cheng, K.T. Ramesh, E. Ma, Effect of nanocrystalline and ultrafine grain sizes on the strain rate sensitivity and activation volume: fcc versus bcc metals, Materials Science and Engineering: A, 381 (2004) 71-79.

[16] A.K. De, J.G. Speer, D.K. Matlock, D.C. Murdock, M.C. Mataya, R.J. Comstock, Deformation-induced phase transformation and strain hardening in type 304 austenitic stainless steel, Metallurgical and Materials Transactions A, 37 1875-1886.

[17] M. Dickson, The significance of texture parameters in phase analysis by X-ray diffraction, Journal of Applied Crystallography, 2 (1969) 176-180.

[18] S. Rajasekhara, L.P. Karjalainen, A. Kyröläinen, P.J. Ferreira, Microstructure evolution in nano/submicron grained AISI 301LN stainless steel, Materials Science and Engineering: A, 527 (2010) 1986-1996.

[19] D.L. Johannsen, A. Kyrolainen, P.J. Ferreira, Influence of Annealing Treatment on the Formation of Nano/Submicron Grain Size AISI 301 Austenitic Stainless Steels, Metallurgical and Materials Transactions. Part A, 
Physical Metallurgy and Materials Science [H.W. Wilson - AST], 37A (2006) 2325.

[20] M. Tokizane, N. Matsumura, K. Tsuzaki, T. Maki, I. Tamura, Recrystallization and formation of austenite in deformed lath martensitic structure of low carbon steels, Metallurgical Transactions A, 13 (1982) 1379-1388.

[21] S. Takaki, K. Tomimura, S. Ueda, Effect of Pre-cold-working on Diffusional Reversion of Deformation Induced Martensite in Metastable Austenitic Stainless Steel, ISIJ International, 34 (1994) 522-527.

[22] D.L. Johannsen, A. Kyrolainen, P.J. Ferreira, Influence of annealing treatment on the formation of nano/submicron grain size AISI 301 Austenitic stainless steels, Metallurgical and Materials Transactions A, 37 (2006) 2325-2338.

[23] R.Z. Valiev, R.K. Islamgaliev, I.V. Alexandrov, Bulk nanostructured materials from severe plastic deformation, Progress in Materials Science, 45 (2000) 103-189.

[24] A. Rezaee, A. Najafizadeh, A. Kermanpur, M. Moallemi, The influence of reversion annealing behavior on the formation of nanograined structure in AISI 201L austenitic stainless steel through martensite treatment, Materials \& Design, 32 (2011) 4437-4442.

[25] P. Behjati, A. Kermanpur, A. Najafizadeh, H.S. Baghbadorani, Effect of annealing temperature on nano/ultrafine grain of Ni-free austenitic stainless steel, Materials Science and Engineering: A, 592 (2014) 77-82.

[26] Y.M. Wang, M.W. Chen, F.H. Zhou, E. Ma, High tensile ductility in a nanostructured metal, NATURE, 419 (2002) 912-915.

[27] I. Shakhova, V. Dudko, A. Belyakov, K. Tsuzaki, R. Kaibyshev, Effect of large strain cold rolling and subsequent annealing on microstructure and mechanical properties of an austenitic stainless steel, Materials Science and Engineering: A, 545 (2012) 176-186.

[28] S. Rajasekhara, P.J. Ferreira, L.P. Karjalainen, A.K.L. Inen, Hall - Petch Behavior in Ultra-Fine-Grained AISI 301LN Stainless Steel, Metallurgical and Materials Transactions A, 38 (2007) 1202-1210.

[29] V.S.A. Challa, X.L. Wan, M.C. Somani, L.P. Karjalainen, R.D.K. Misra, Strain hardening behavior of phase reversion-induced nanograined/ultrafine-grained (NG/UFG) austenitic stainless steel and relationship with grain size and deformation mechanism, Materials Science and Engineering: A, 613 (2014) 60-70.

[30] I. Gutierrez-Urrutia, D. Raabe, Dislocation and twin substructure evolution during strain hardening of an $\mathrm{Fe}-22 \mathrm{wt} . \%$ Mn - 0.6wt.\% C TWIP steel observed by electron channeling contrast imaging, Acta Materialia, 59 (2011) 6449-6462.

[31] V.S.A. Challa, X.L. Wan, M.C. Somani, L.P. Karjalainen, R.D.K. Misra, Strain hardening behavior of phase reversion-induced nanograined/ultrafine-grained (NG/UFG) austenitic stainless steel and relationship with grain size and deformation mechanism, Materials Science and Engineering: A, 613 (2014) 60-70.

[32] V. Yamakov, D. Wolf, S.R. Phillpot, A.K. Mukherjee, H. Gleiter, Deformation-Mechanism Map for Nanocrystalline Metals by Molecular-Dynamics Simulation, Nature Materials, 3 (2004) 43-7.

[33] X.Z. Liao, F. Zhou, E.J. Lavernia, S.G. Srinivasan, M.I. Baskes, D.W. He, Y.T. Zhu, Deformation mechanism in nanocrystalline Al: Partial dislocation slip, Applied Physics Letters, 83 (2003) 632-634.

[34] C.X. Huang, K. Wang, S.D. Wu, Z.F. Zhang, G.Y. Li, S.X. Li, Deformation twinning in polycrystalline copper at room temperature and low strain rate, Acta Materialia, 54 (2006) 655-665.

[35] S. Cheng, J.A. Spencer, W.W. Milligan, Strength and tension/compression asymmetry in nanostructured and ultrafine-grain metals, Acta Materialia, 51 (2003) 4505-4518. 
Fig. 1. The microstructure of the solution-treated as-received austenitic stainless steel.

Fig. 2. XRD spectra for cold-rolled and annealed samples.

Fig. 3. TEM micrographs illustrating the representative microstructure of cold rolled sample with $\sim 75 \%$ cold reduction. (a) mixed microstructure of lath martensite and dislocation cell type martensite, (b) high magnification of lath martensite and (c) high magnification of dislocation cell type martensite.

Fig. 4. SEM micrographs of the specimens with average grain size of (a) $220 \mathrm{~nm}\left(700{ }^{\circ} \mathrm{C}\right.$ for $\left.20 \mathrm{~s}\right)$, (b) $400 \mathrm{~nm}\left(750{ }^{\circ} \mathrm{C}\right.$ for $\left.5 \mathrm{~s}\right),(\mathrm{c}) 1.23 \mu \mathrm{m}\left(800{ }^{\circ} \mathrm{C}\right.$ for $\left.20 \mathrm{~s}\right)$ and (d) $3.23 \mu \mathrm{m}\left(900{ }^{\circ} \mathrm{C}\right.$ for $\left.20 \mathrm{~s}\right)$ subjected to $\sim 75 \%$ cold reduction.

Fig. 5. TEM micrographs of the specimens with average grain size of (a) $220 \mathrm{~nm}$, (b) $400 \mathrm{~nm}$, (c) $1.23 \mu \mathrm{m}$ and (d) $3.23 \mu \mathrm{m}$.

Fig. 6. The relationship between grain size and yield strength of $17 \mathrm{Cr}-6 \mathrm{Ni}$ austenitic stainless steel.

Fig. 7. (a) True stress-strain $(\sigma-\varepsilon)$ curves and (b) work hardening plots for different grain sizes.

Fig. 8. Representative TEM micrographs of coarse-grained ASS $(3.23 \mu \mathrm{m})$ illustrating deformation structure (a) at true strain of 0.1 and (b) in the vicinity of fracture region.

Fig. 9. Representative TEM micrographs of nano/ultrafine grained ASS (220 nm) illustrating (a) DIM, (b) deformation twins at true of 0.1 , (c) deformation twins and (d) dislocation structures in the vicinity of fracture region.

\section{Table 1}

Chemical composition of experimental steel in weight \%, along with $\mathrm{M}_{\mathrm{d} 30}, \mathrm{M}_{\mathrm{s}}, \mathrm{Ni}_{\mathrm{eq}}$.

\section{Table 2}

Relative intensities of the measured reflections of martensite and austenite.

\section{Table 3}

Grain size, $\%$ austenite and mechanical properties of steel annealed at different temperatures. 


\section{Table 1}

Chemical composition of experimental steel in weight $\%$, along with $\mathrm{M}_{\mathrm{d} 30}, \mathrm{M}_{\mathrm{s}}, \mathrm{Ni}_{\text {eq }}$.

\begin{tabular}{ccccccccc}
\hline $\mathrm{C}$ & $\mathrm{Si}$ & $\mathrm{Mn}$ & $\mathrm{Ni}$ & $\mathrm{Cr}$ & $\mathrm{Cu}$ & $\mathrm{M}_{\mathrm{d} 30}\left({ }^{\circ} \mathrm{C}\right)$ & $\mathrm{M}_{\mathrm{s}}\left({ }^{\circ} \mathrm{C}\right)$ & $\mathrm{Ni}_{\mathrm{eq}}$ \\
\hline 0.0551 & 0.062 & 1.314 & 6.092 & 17.159 & 2.08 & 38.7 & -90.4 & 22.37 \\
\hline
\end{tabular}


Table 2

Relative intensities of the measured reflections of martensite and austenite.

\begin{tabular}{c|c|c|c}
\hline \multicolumn{2}{c|}{ Martensite } & \multicolumn{2}{c}{ Austenite } \\
\hline Bragg reflections & $\mathrm{R}_{\alpha}$ & Bragg reflections & $\mathrm{R}_{\gamma}$ \\
\hline 110 & 1628 & 111 & 1196.8 \\
200 & 251.4 & 200 & 566.7 \\
211 & 457.95 & 220 & 326.7 \\
\hline
\end{tabular}


Table 3

Grain size, \% austenite and mechanical properties of steel annealed at different temperatures.

\begin{tabular}{ccccc}
\hline $\begin{array}{c}\text { Average Grain } \\
\text { size }(\mu \mathrm{m})\end{array}$ & Vol.\% of austenite & $\begin{array}{c}\text { Yield } \\
\text { Strength(MPa) }\end{array}$ & $\begin{array}{c}\text { Tensile } \\
\text { Strength(MPa) }\end{array}$ & $\begin{array}{c}\text { Total } \\
\text { Elongation(\%) }\end{array}$ \\
\hline CR & 4.68 & - & 1678 & - \\
0.22 & 85.84 & 973 & 1073 & 31.5 \\
0.4 & 97.65 & 790 & 1038 & 40.5 \\
0.66 & 98.58 & 762 & 991 & 35.6 \\
1.23 & 100 & 481 & 850 & 42.0 \\
2.29 & 100 & 417 & 791 & 46.0 \\
3.23 & 100 & 350 & 739 & 55.5 \\
25.30 & 100 & 290 & 737 & 67.3 \\
\hline
\end{tabular}




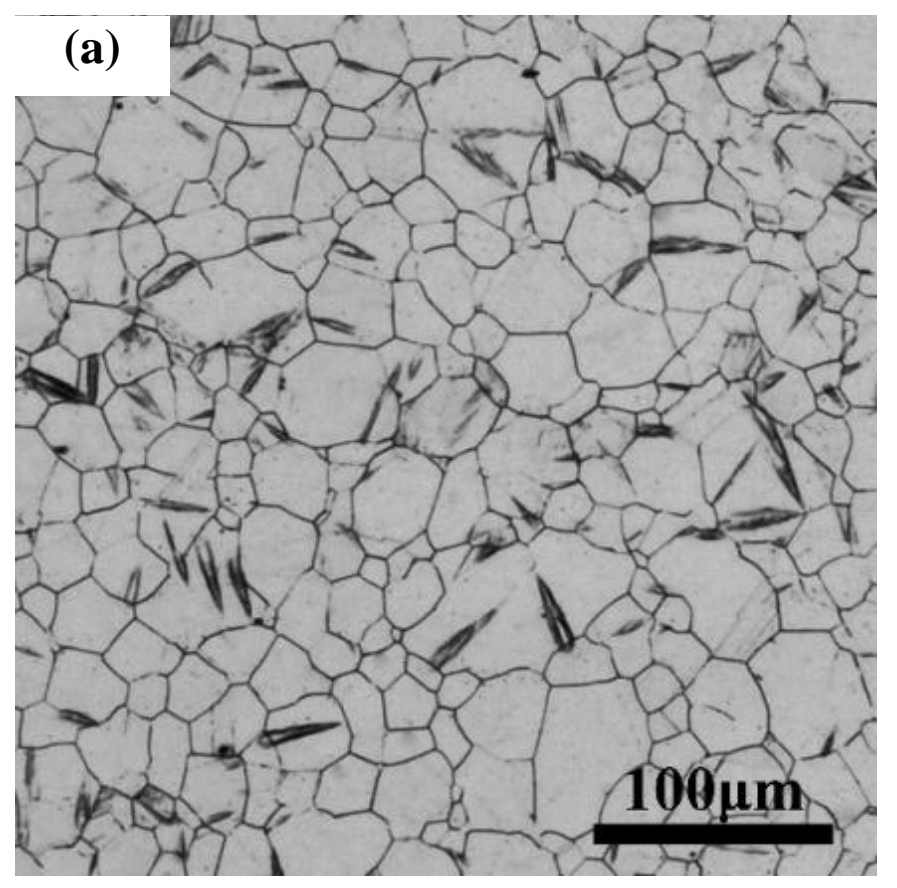

Fig. 1. The microstructure of the solution-treated as-received austenitic stainless steel.

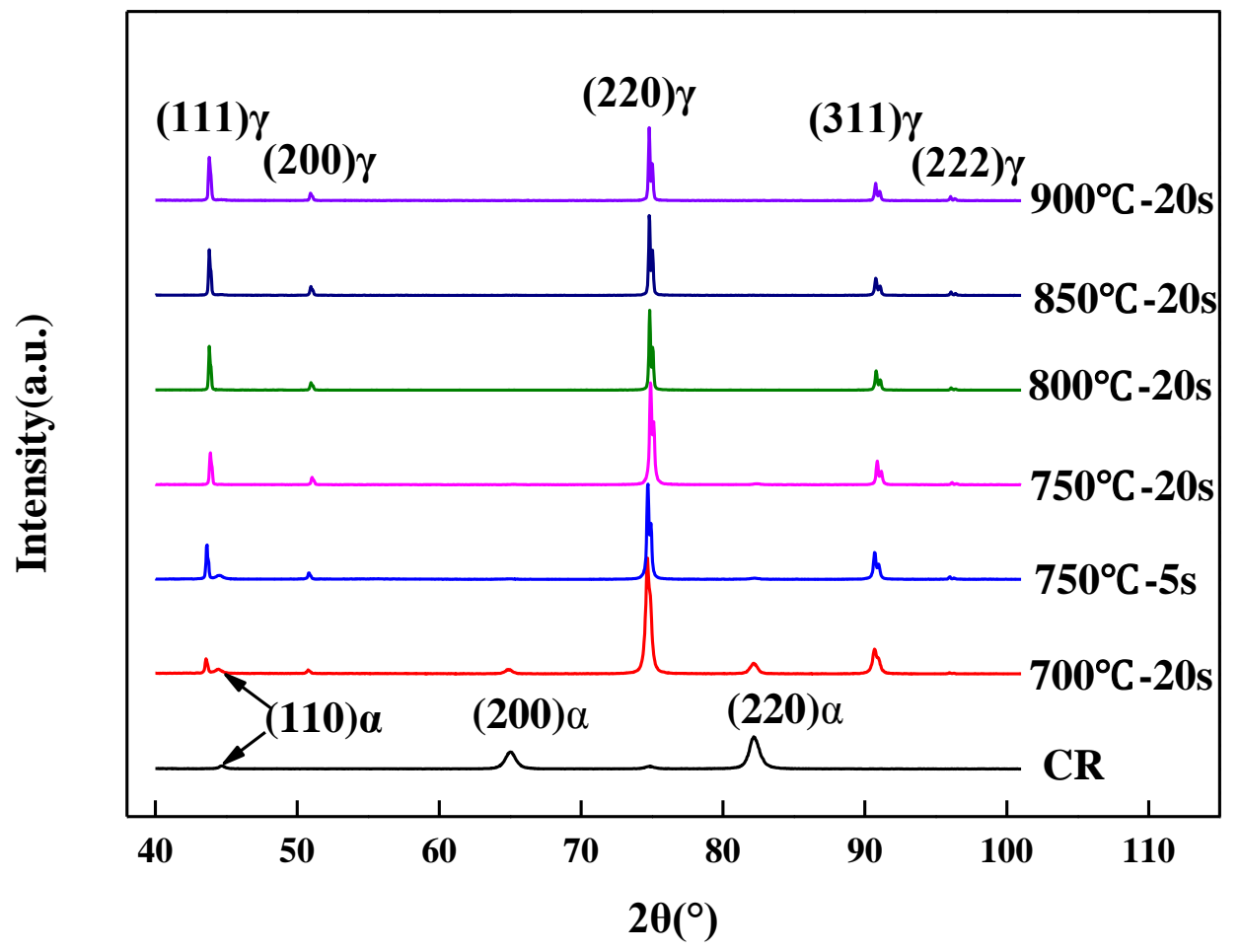

Fig. 2. XRD spectra for cold-rolled and annealed samples. 

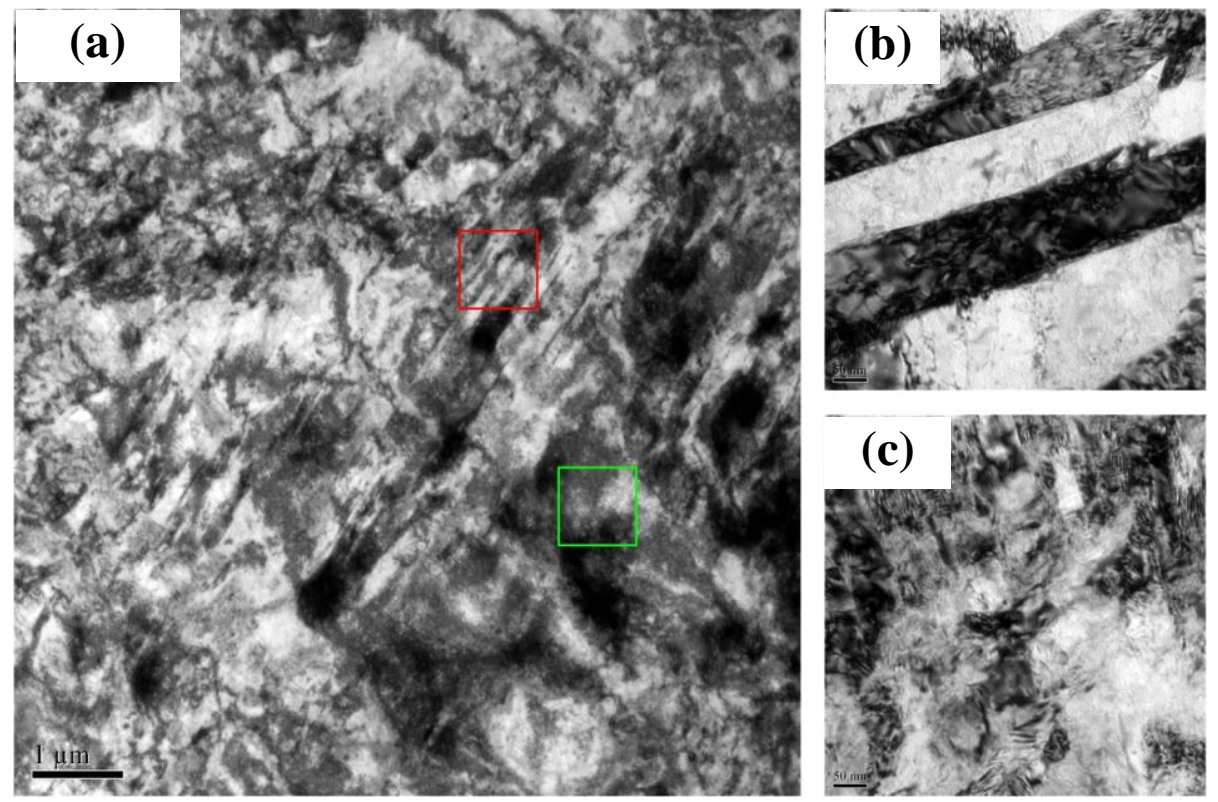

Fig. 3. TEM micrographs illustrating the representative microstructure of cold rolled sample with $\sim 75 \%$ cold reduction. (a) mixed microstructure of lath martensite and dislocation cell type martensite, (b) high magnification of lath martensite and (c) high magnification of dislocation cell type martensite. 

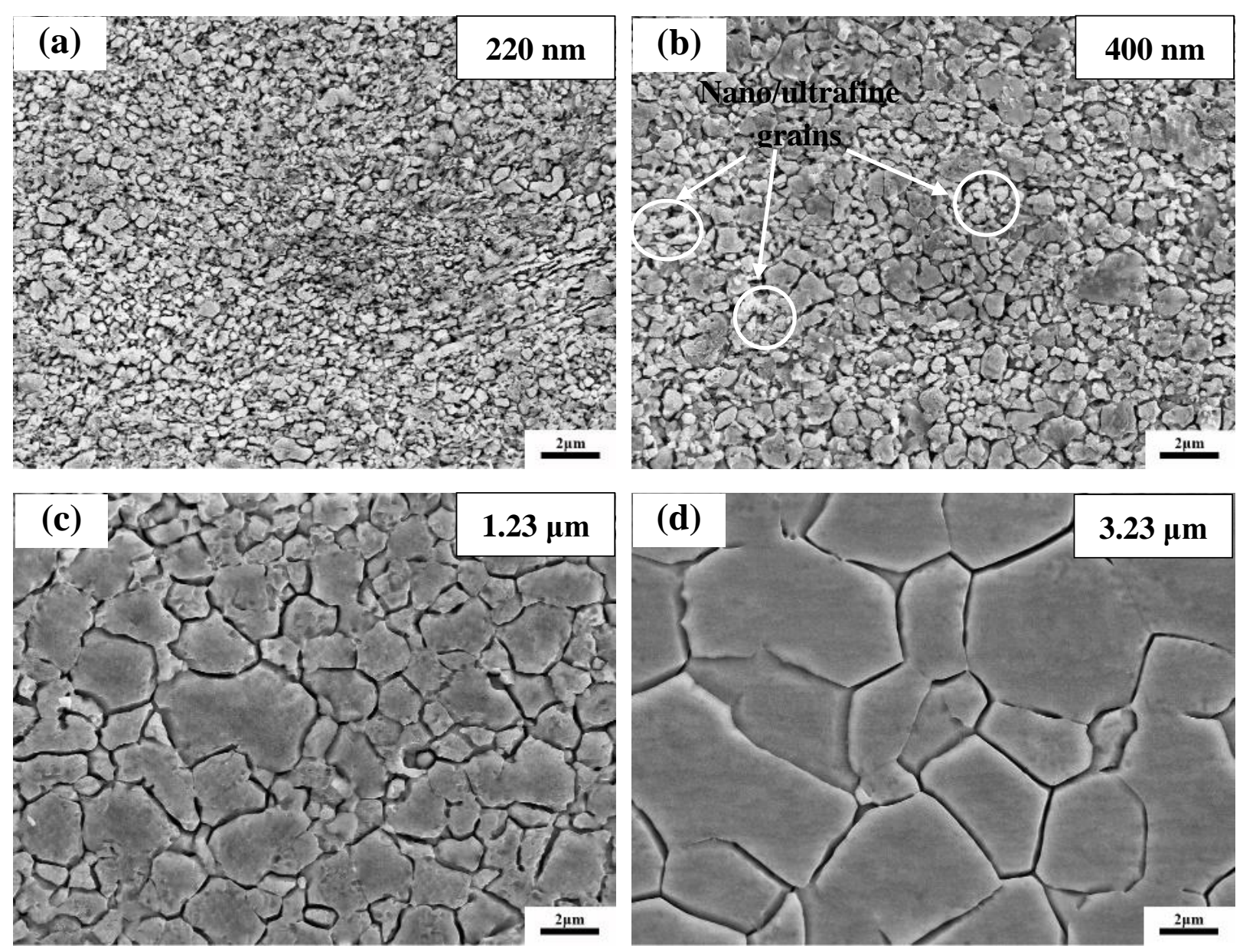

Fig. 4. SEM micrographs of the specimens with average grain size of (a) $220 \mathrm{~nm}\left(700{ }^{\circ} \mathrm{C}\right.$ for $20 \mathrm{~s}$ ), (b) $400 \mathrm{~nm}\left(750{ }^{\circ} \mathrm{C}\right.$ for $\left.5 \mathrm{~s}\right),\left(\right.$ c) $1.23 \mu \mathrm{m}\left(800{ }^{\circ} \mathrm{C}\right.$ for $\left.20 \mathrm{~s}\right)$ and (d) $3.23 \mu \mathrm{m}\left(900{ }^{\circ} \mathrm{C}\right.$ for $\left.20 \mathrm{~s}\right)$ subjected to $\sim 75 \%$ cold reduction. 

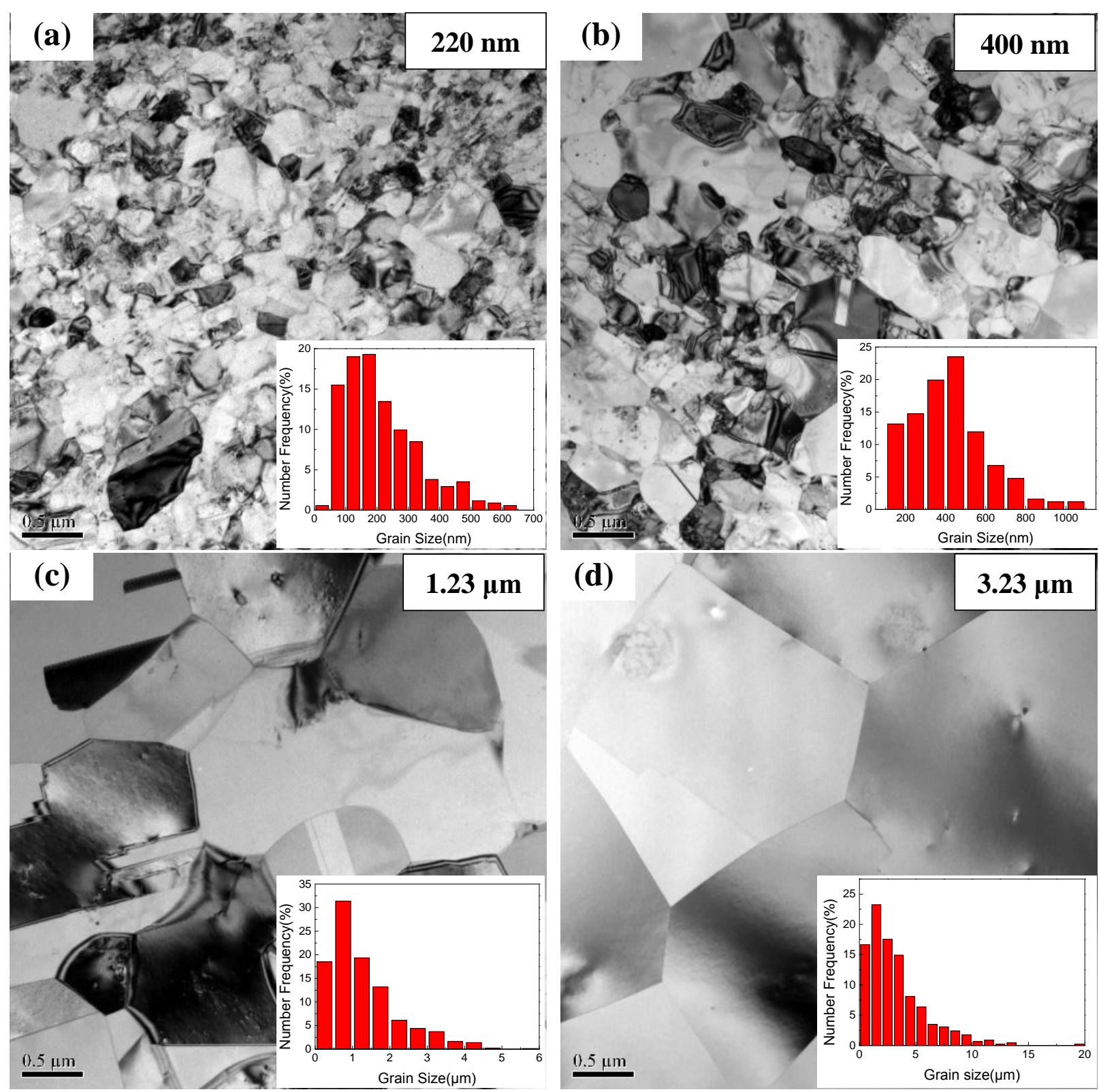

Fig. 5. TEM micrographs of the specimens with average grain size of (a) $220 \mathrm{~nm}$, (b) $400 \mathrm{~nm}$, (c) $1.23 \mu \mathrm{m}$ and (d) $3.23 \mu \mathrm{m}$. 


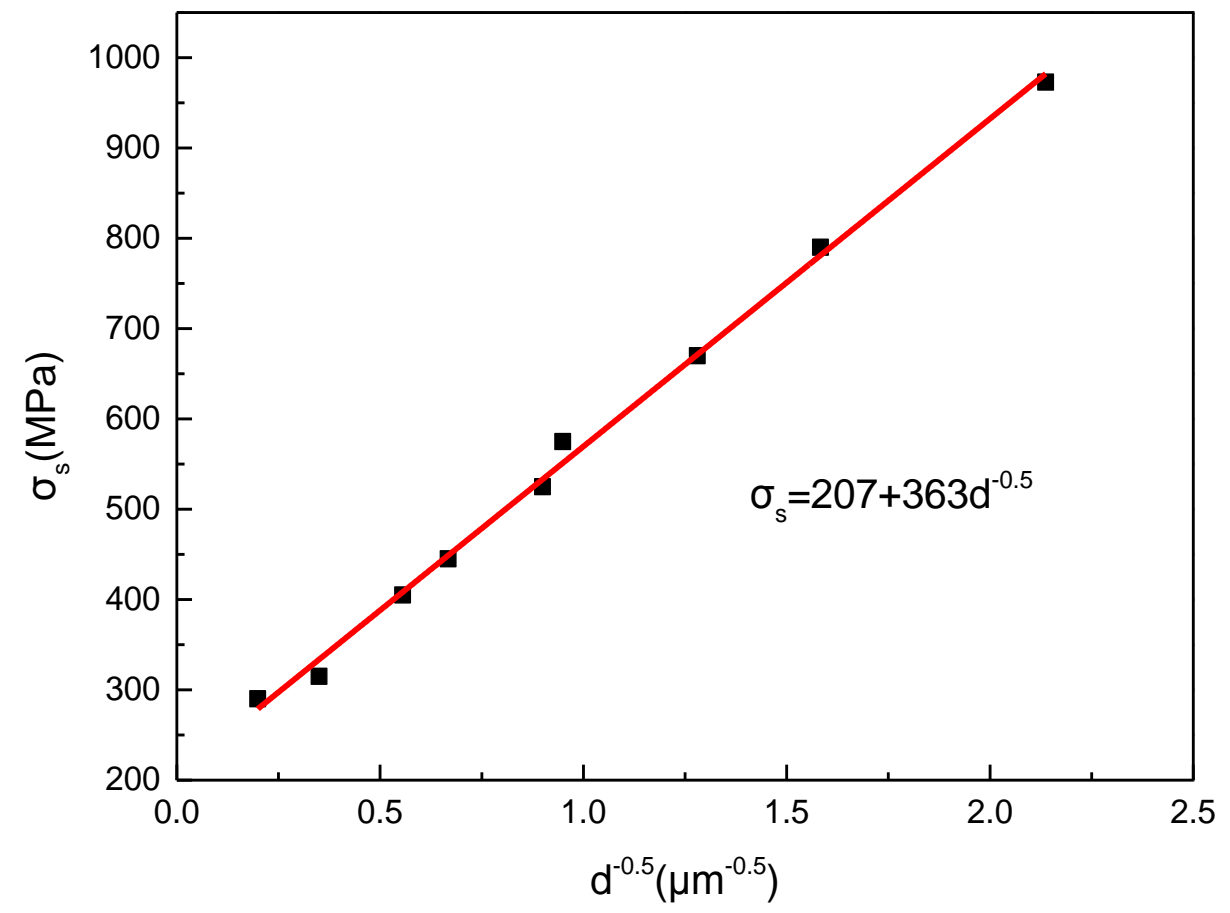

Fig. 6. The relationship between grain size and yield strength of $\mathrm{Fe}-17 \mathrm{Cr}-6 \mathrm{Ni}$ austenitic stainless steel.
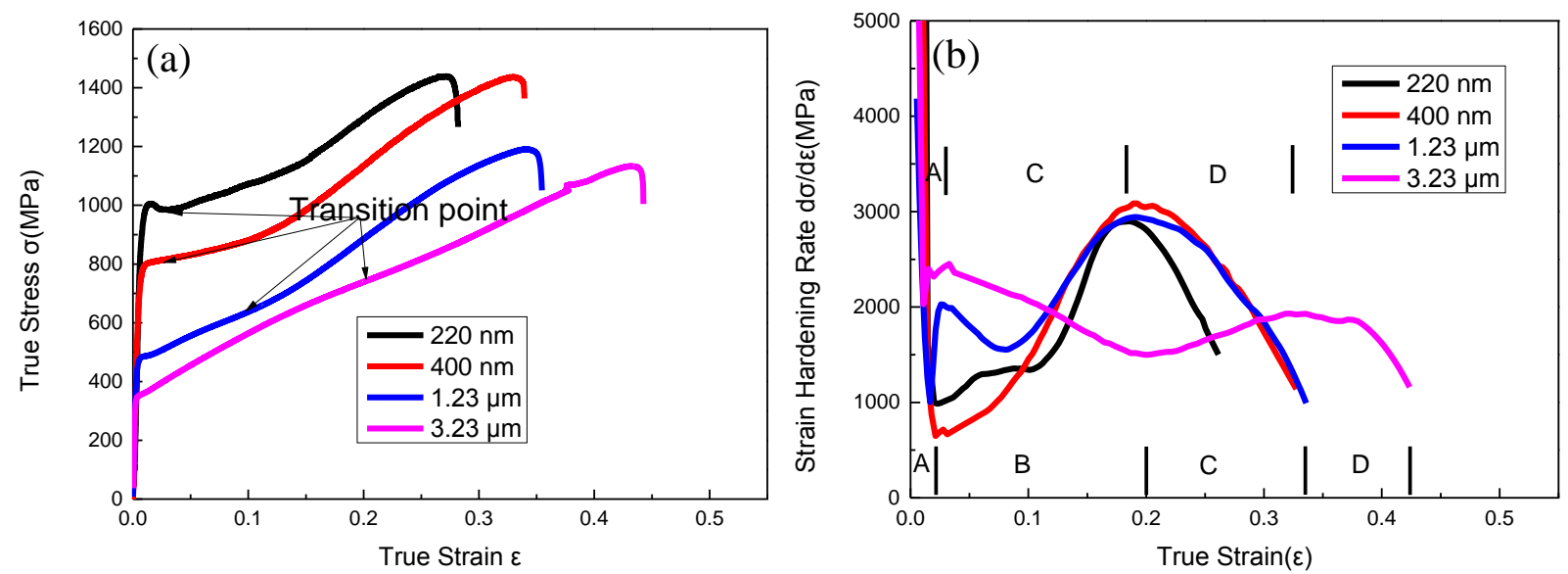

Fig. 7. (a) True stress-strain $(\sigma-\varepsilon)$ curves and (b) work hardening plots for different grain sizes. 

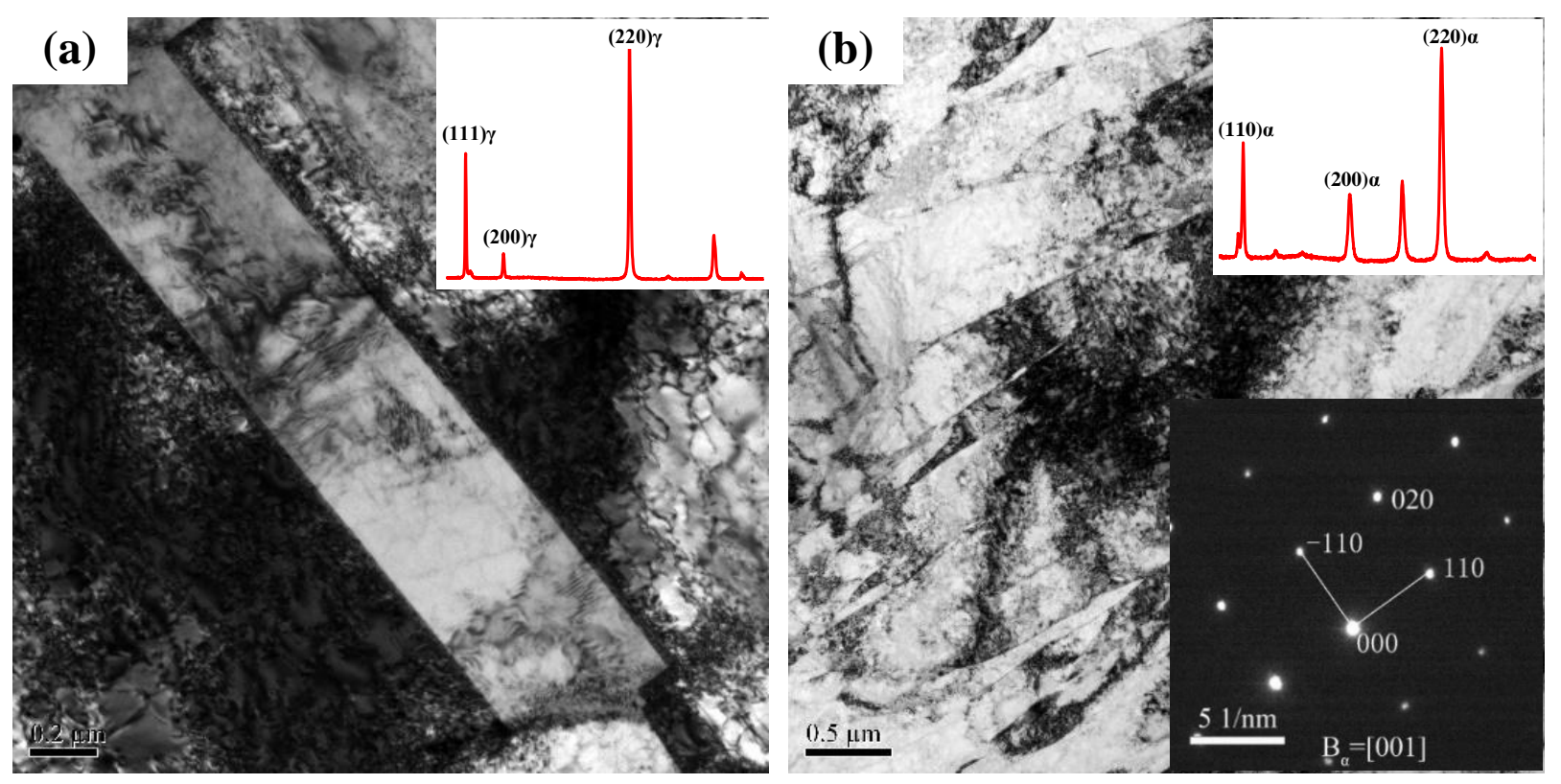

Fig. 8. Representative TEM micrographs of coarse-grained ASS $(3.23 \mu \mathrm{m})$ illustrating deformation structure (a) at true strain of 0.1 and (b) in the vicinity of fracture region. 

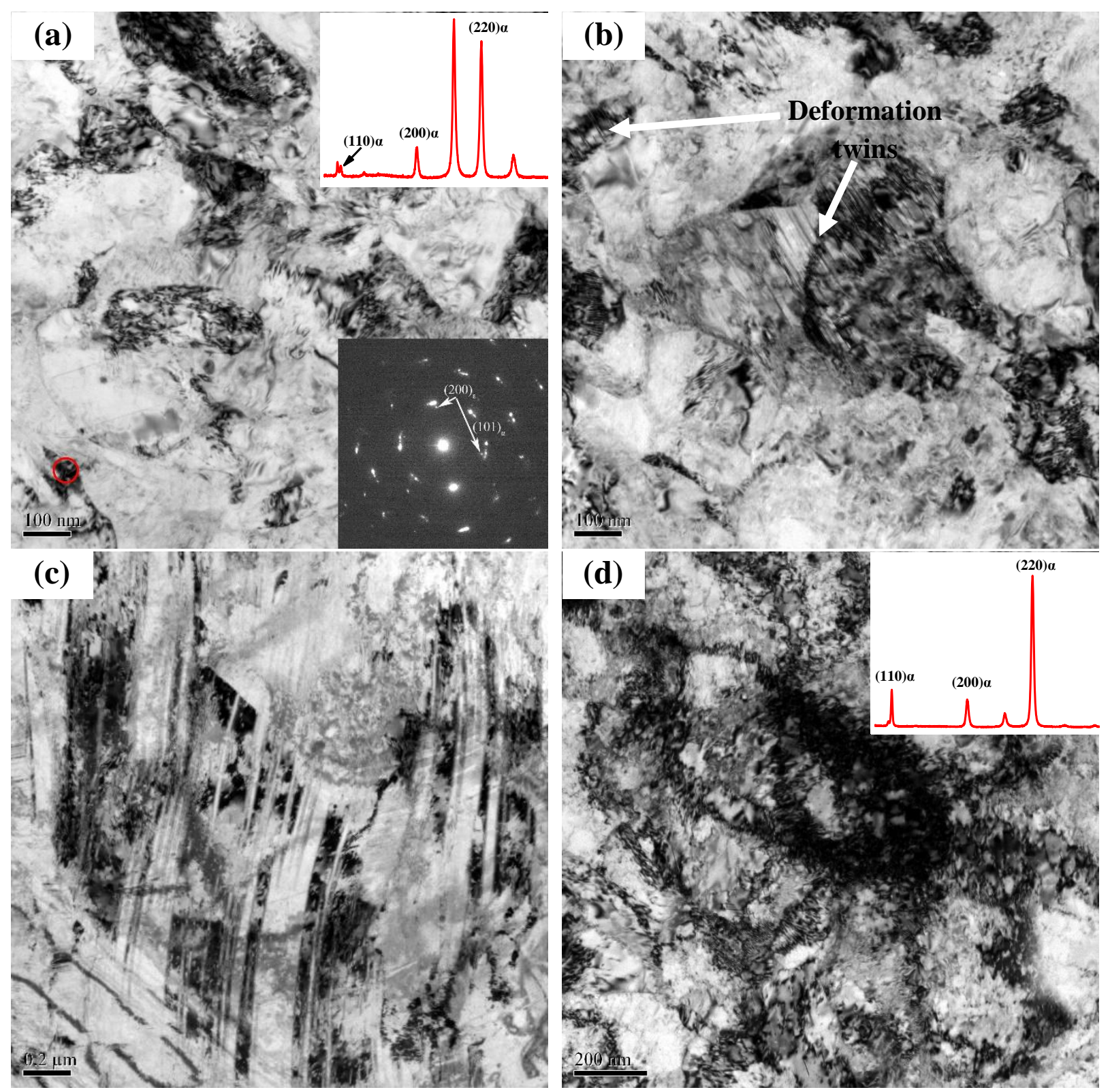

Fig. 9. Representative TEM micrographs of nano/ultrafine grained ASS (220 nm) illustrating (a) DIM, (b) deformation twins at true of 0.1 , (c) deformation twins and (d) dislocation structures in the vicinity of fracture region. 